\title{
KepuasanKerja Pada Karyawan Ditinjau Berdasarkan Faktor Demografik dan Motif Berprestasi
}

\author{
Rostiana D. Nurjayadi \\ Universitas Tarumanagara
}

\begin{abstract}
This research tries to find the relationship among achiovement motivation, demographics factors and job satisfaction. The participants are 55 administration employees of one private universily in west Jakarta. Data collection were held during \pm 2 months and to be analyzad by using Pearson Product Moment correlation. Result indicated there are significant correlations between achievement motivation and job satisfaction $(r=+0,312, p<0,05)$, between age and job satisfaction $(r=-0,315, p<0,05)$, between work time and job satisfaction $(r=-0,459$, $p<0,05)$. The relationship findings between demographics factors and job satisf action did not support the previous research that found positive correlations between age, work time and job satisfaction.
\end{abstract}

Key words: Job satisfaction, achievernent motivation and dernogr aphic factors

\section{Pendahuluan}

epuasan kerja merupakan salah satu konstruk psikologi yang banyak sekali mendapat perhatian dari para peneliti. Senantiasa ada berbagai upaya penelitian untuk mengkaji secara leblh mendalam konstruk tersebut antara lain karena kepuasan kerja tampaknya merupakan suatu muara dan sekallgus juga sebagai sarana untuk memahami perilaku kerja.

Dikatakan sebagai muara, kepuasan kerja merupakan tujuan yang ingin dicapai oleh semua pekerja sehingga berbagal macam perilaku kerja serta berbagai kajian tentang aneka variabel pada organisasi akhirnya diarahkan pada kepuasan kerja. Dengan demiklan, secara otomat's kepuasan kerjapun menjadi sarana untuk mempelajari dan mernahami apa saja yang dijakukan oleh pekerja agar ia mencapai tingkat kepuasan yang diinglnkan.

Penelitlan ini juga berupaya mengkaji kepuasan kerja pada karyawan administrasi suatu organlsasi pendidikan. Seringkali penelitian ataupun kajlan perilaku kerja pada organisasi pendidikan lebih banyak difokuskan kepada tenaga pengajar ataupun peserta didik. Sejauh Ini kajlan terhadap perilaku kerja karyawan administrasl tampaknya masih kurang. Mesklpun tidak dapat disangkal bahwa peran mereka cukup signifikan terhadap kelancaran kerja organisasi, namun adanya anggapan bahwa peran mereka hanya sebagai 
penumjang membuat kajian terhadap perilaku kerja mereka terabaikan.

Berdasarkan pertimbangan tersebut, penelitian ini mencoba untuk menelaah kepuasan kerja karyawan administratif yang akan ditinjau berdasarkan aspek demografisnya, antara lain lama kerja, usia dan perbedaan jenis kelarnin serta aspek motivasi berpresłasi. Berangkat dari adanya anggapan bahwaperan karyawanadministrasi merypakan peran penunjang, ingin diketahui apakah mereka tetap mempunyai atau memperlihatkan hasrat berprestasi dalam melakukan pekerjaannya. Selain itu ingin diketahui lebih lanjut apakah motivasi berprestasi tersebut mempuryai hubungan yang bermaknadengan kepuasan kerja mereka. Dengan demikian hasi penelitian ini diharapkan dapat mendeskripsikan sejauh mana tingkat kepuasan kerja dan tingkat motivasi berprestasi karyawan administrasi tersebut serta sejauh mana hubungan antara faktor demografis dan motivasi berprestasi dengan kepuasan kerja mereka.

\section{Kepuasan kerja}

Dalam pandangan Baron \& Greenberg (1997) kepuasan kerja merupakan suatu hasil evaluasi baik secara kognitif dan afektif terhadap pekerjaan. Dengan demikian kepuasan kerja mencerminikan bagaimana seseorang berpikir tentang pekerjaannya dan merasakan sejauh mana pekerjaan tersebut mendatangkan kepuasan bagi dirinya. Secara lebih singkat Munandar (2001) mengatakan bahwa kepuasan kerja mencerminkan sikap tenaga kerja terhadap pekerjaannya. Sejauh sikapnya positif, kepuasan kerjanya jug a juga akan lebih tinggi daripada jika sikapnya negatif terhadap pekeriaan.

Penilaian yang dilakukan pekerja terhadap pekerjaannya akan menghasilkan kesesuaian atau ketidaksesuaian antara kebutuhan yang harus dipenuhi dengan karakteristik pekerjaan. Sehubungan dengan hal iniAnastasi (1993) mengemukakan bahwa semakin sesual kedua aspek tersebut, semakin tinggi tingkat kepuasan kerja yang dicapai, sebaliknya semakin tidak sesuai, semakin rendah tingkat kepuasan kerjanya.

Thierry (dalam Drenth, Thierry \& De Wolff, 1998) mengemukakan bahwa kepuasan keria terkait dengan motivasi seseorang untuk melaksanakan tugas. Menurutnya kepuasan memainkan peranan penting pada setiap teori motivasi. Oleh karena itu tidak mengherankan jika teori-teori tentang motivasi kerja juga banyak digunaken untuk menelaah kepuasaan kerja. Misalnya saja, kepuasan menurut toori Maslow akan terpenuhi jika motif pada hierarki yang lebih tinggi terpenuhi. Dalam hal ini jelas terlihat bahwa kepuasan merupakan hasil dari proses pemenuhan motif. Dalam rangka memenuhi motif atau kebutuhan, seseorang akan berusaha memperlihatkan kinerja yang optimal. Kiner ja ini akan menentukan imbalan yang akan ia terima dengan konsekuensi jika imbalan (tidak hanya bersifat fisik) sesuai dengan harapennya, maka kepuasan akan tercapal. Sebaliknyajika tidak terpenuhi maka kepuasan tidak tercapai.

Robbins (1996) berpendapat jike ingin mencapai kepuasan kerja ada 5 (lima) faktor yang perlu dipenuhi yaitu: (1). Tugas yang ditangani haruslah tugas yang menantang, jadi bukan tugas-tugas yang bersifat rutin dan sederhana. (2). Pekerja memperoleh imbalan yang pantas atau sesuai dengan jerih payahnya dal ii menyelesaikan tugas tersebut. (3).Kondisi kerja yang ada menunjang kelancuran tugas sehingga pekerja tidak memperoleh hambatan dalam menyelesaikan tugas. (4).Adanya bantuan dari rekan sekerja. Dalam hal ini dukungan ataupun bantuan dibutuhkan terutama pada saat pekerja mengalami situasi yang menyulitkan. (5). Adanya kesesuaian antara karakteristik kepribadjan dengan ciri-ciri pekerjaan yang dilakukan.

Secara lebih rinci faktor-faktor tersebut dikemukakan oleh Dubrin (1992). Dubrin membagi faktor tersebut kedalam dua kelompok, yaitu faktor eksternal dan faktor internal. Faktor eksternal yang mempengaruhi kepuasan kerja antara lain adalah: tugas yang menantang; tuntutan fisik pekerjaan yang massuk akal, adanya kontak dengan konsumen; diberikan tanggung jawab pribadi dalam 
menyelesaikan tugas; adanya kebebasan untuk mengatur jadwal peker jaan; memperoleh imbalan yang berrnakna; memperoleh bantuan dari rekan dan atasan, terakhir, memiliki kekuasaan dan otoritas untuk mengerjakan tugas. Sedangkan faktor internal yang mempengaruhi kepuasan keria mencakup: minat terhadap pekerjaan; harga diri yang terbentuk berkaitan dengan jenis tugas yang ditangani; optimistik \& adanya fleksibilitas dalam bekerja; memiliki konsep diri positif; dapat menyesuaikan diri serta mempunyai harapan positifterhadap pekerjaan.

Dikaitkan dengan faktor demografik, Schultz \& Schultz (1990) mengungkapkan sebagai berikut: Ada perbedaan kepuasan kerja pada laki-laki dan perempuan. Perempuan merasa kurang puas terhadap pekerjaannya dibandingkan laki-laki antara lain karena adanya diskriminasi dalam hal gaij, pencapaian karir dan wewenang dalam menjialankan tugas. Ditinjau dari aspek usia, kepuasan kerja meningkat sejalan dengan pertambahan usia dari pekerja Sementara ditinjau dari aspek pendidikan ternyata kepuasan kerja berkorelasi negatif dengan pendidikan, terutama dalam kondisi pekerja dengan pendidikan yang tinggi namun memperoleh tugas-lugas yang dipandang tidak sebanding dengan tingkat pendidikannya.

\section{Motif berprestasi}

Konsep ini mencuat ketika McClelland (1987) mengungkapkan teori mengenai motif sosial. Menurutnya ada 3 macam motif yang mendasari hubungan sosial. Ketiganya akan memunculkan perilaku yang berbeda ketika seseorang menjalin hubungan dengan orang lain. Ketiga motif tersebut adalah motif berkuasa (power motive), motif bersahabat (affiliation motive) dan motif berprestasi (achievement motive). Di antara ketiganya, motif berprestasi dipandang sebagai konsep yang memiliki peran cukup besar dalam mengkaji perilaku organisasi.

Motif berprestasi menurut Mcclelland merupakan suatu kebutuhan untuk memberikan prestasi yang mengungguli standar. Dengan motif berprestasi yang besar seseorang akan mengerjakan sesuatu secara optimal karena mengharapkan hasl yang lebin baik dari standar yang ada.

Dalam pandangan Murray ( $\mathrm{Hall} \&$ Lindzey, 1993) individu yang memiliki motif berprestasi tinggi akan memperlihatkan ciri-ciri antara lain ingin menyaingi ataus mengungguli orang lain: berypaya untuk meningkatkan harga din melabi penyaluran bakat/kemampuan secara sukses; adanya dorongan untuk menyelesaikan tugastugas yang sulit; ingin menguasai, memanipulasi dan mengatur lingkungannya agar dapat menunjang pencapaian prestasi; ada kebutuhan yang besar untuk bisa mandiri dan mencapai standar tinggi.

Selain ciri $d$ atas individu dengan motif berprestasi tinggi juga memperlihatkan ciri-ciri seperti tidak menyukai risiko tinggi dalam menjalankan tugas, mereka lebih memilin tugas-tugas yang dipersepsikan akan dapat diselesaikan dengan mutu tinggi daripada tugas-tugas yang lebih sulit namun hasilnya tidak pasti. Mereka juga memperlinatkan orientasi terhadap tugas (task oriented) yang tinggi dalam bekerja dengan konsekuensi sulit bekerja dalam tim yang tidak sejalan dengan orientasinya. (Kolb, Osland \& Rubin, 1995).

Hersey, Blanchard \& Johnson (1996) menambahkan ciil d atas, antara lain, individu dengan motif berprestasi tinggi merasa lebih tertarik kepada prestasi yang dihasilkan daripada imbalan. Mereka tidak menolak imbalan namun hal terse but bukan hal utama dan kurang berperan penting bagi dirinya daripada prestasi yang dihasilkan atas namanya sendiri. Dalam bekerja mereka akan menampilkan diri apa adanya, tidak terlalu banyak berbasa-basi dan lebih banyak menghabiskan waktu untuk berpikir mencari cara untuk menyelesaikan tugas secara lebih efektif dan efisien. Biasanya orang-orang dengan motif berprestasi tinggi menjadi tulang punggung organisasi dan mereka akan efektif bila mengerjakan tugas yang bersifat mandiri. Seringkali mereka justru gagal bila keberhasilan tugasnya banyak tergantung kepada orang lain. Dalam posisi sebagai manajer. 
mereka seringkali bersikap kurang sabar dan kurang terampil melakukan pendekatan interpersonal.

Seperti halnya dengan konstruk kepribadian yang lain, motif berprestasi bukan fakbr bawaan. Konstruk tersebut terbentuk karena pengaruh lingkungan, khususnya pola asuh. Heckhousen (dalam McClleland, 1987) mengungkapkan motif berprestasi mulai terbentuk ketika anak berusia \pm 3 tahun, khususnya ketika anak mulai dapat membedakan antara keberhasilan dan kegagalan. Jika lebih banyak køberhasilan yang dialaml anak, maka keinginan untuk memperoleh prestasi akan mewarnai motif berprestasinya kelak ia dewasa. Sebaliknya jika kegagalan yang banyak dirasakan maka motif berprestasinya akan lebth dipengaruhi oleh ketakutan akan kegagalan. Seringkali motif berprestasi yang didasari oleh keinginan memperoleh prestasi lebih banyak mendatangkan kesuksessan dalam pendidkan ataupun bekeria Sedangkan motif berprestasi yang didasari oleh ketakutan akan kegagalan justru banyak mendatangkan kecemasan dan kecenderungan untuk menghindari konflik sehingga memerlukan pengerahan dan pengelolaan energi yang banyak untuk mencapaj kesuksessan.

Lebih lanjut Robbins (1996) menjelaskan pada usia tersebut anak mulai memperlihatkan perilaku kompetitif dan mulai muncul keinginan untuk melakukan sesuatu lebih cepat dan lebih baik dari teman-temannya. Dengan demikian motif berprestasi akan berkemburry baik apabila pada masa kanak-kanak orangtua dapat memberikan peluang dan kebebasan pada anak untuk mencoba atau mengeksplorasi sesuatu dengan tidak terlalu banyak menuntut dan tidak memberikan hukuman jika anak mengalami kegagalan.

Seperti telah dikemukakan bahwa motif berprestasi mendorong seseorang untuk berperilaku aktif dalam bekerja sehingga dapa: melakukan banyak hal untuk instansinya. Dengan begitu dapat dlasumsikan banyak kebutuhan yang dapat terpenuhi sehingga kepuasan kerja yang tinggi akan tercapai. Berdasarkan uraian di atas dapat ditarik suatu hipotesa bahwa semakin tinggi motif berprestasi seseorang, semakin tinggi pula kepuasan kerja yang akan diperolehnya.

\section{Metode Penelitian}

Penelitian ini bersifat deskriptiffinferensial, dalam arti melalui penelitian ini ingin dideskripsikan atau dijabarkan gambaran masing-masing variabel pada sampel ini. Selain itu juga ingin dibuktikan apakah terdapat hubungan yang signifikan antara ketiga variabel penelitian.

Ada 3 variabel yang digunakan dalam penelitian ini, yaitu : Kepuasan kerja, motif berprestasi dan data demografik. Kepuasan kerja didefinisikan sebagai derajat kepuasar karyawan terhadap berbagai hal yang terkaih dengan pelaksanaan pekerjaan dan kebijakan organisasi yang meliputi dimensi antara lain ganjaran, hubungan atasan-bawahan, karaktristik pekerjaan, kondsi kerja. Sedangkan motif berprestasi didefinisikan sebagai besar-kecilnya dorongan untuk melaksanakan tugas sebaik mungkin dengan menampilkan prestasi kerja yang optimal. Faktor demografi yang ditinjau dalam penelitian ini adalah usia dan lama kerja serta jenis kelamin.

Subyek penelitian berjumlah 55 orang karyawan administrasi (bagian pendidikan, umum, keuangan, personalia, perpustakaan) baik dari fakultas maupun rektorat, dengan karakteristik sebagai berikut:

c. Jenis kelamin subyek penelitian terbagi hampir merata antara laki-laki dan perempuan, seperti tertera pad a tabel di bawah ini.

Tabel 1.

Jenis Kolamin Subyek Penslitian

\begin{tabular}{cc}
\hline \multicolumn{2}{c}{ Jumlah Subyek } \\
\hline Laki-Laki & Perempuan \\
\hline $28 / 51 \%$ & $27 / 49 \%$ \\
\hline
\end{tabular}

b. Penyebaran usia subyek penelitian berkisar antara 20 ñ 51 tahun (lihat tabel 2) dengan frekuensi terbesar berada pada 
rentang usia antara 30 ñ39 tahun. Dapat dikatakan bahwa hampir separuh dari subyek sedang beradapadausiaproduktif.

Tabel2.

Penyebaran Usia Subyek Penelltian

\begin{tabular}{cccc}
\hline Usia & Frekuensi Persentase & $\begin{array}{c}\text { Persentase } \\
\text { kumulatif }\end{array}$ \\
\hline $20-29$ & 7 & 12.7 & 12.7 \\
$30-39$ & 26 & 47.3 & 60.0 \\
$40-49$ & 20 & 36.4 & 96.4 \\
$>50$ & 2 & 3.6 & 100.0 \\
\hline Total & 55 & 100.0 & \\
\hline
\end{tabular}

c. Lama kerja seluruh subyek penelitian berkisar antara 4 - 31 tahun dan terlihat dari tabel of bawah ini masa kerja subyek yang paling banyak berkisar antara 10 . 14 tahun.

Tabel 3.

Golongan Lama Kerja (dalam tahun)

\begin{tabular}{cccc}
\hline $\begin{array}{c}\text { Lama } \\
\text { keria }\end{array}$ & Frekuensi Persentase & $\begin{array}{c}\text { Persentase } \\
\text { kumulatif }\end{array}$ \\
\hline $0-4$ & 3 & 5.5 & 5.5 \\
$5-9$ & 16 & 29.1 & 34.5 \\
$10-14$ & 18 & 32.7 & 67.3 \\
$15-19$ & 11 & 200 & 87.3 \\
$20-24$ & 6 & 10.9 & 98.2 \\
$25-29$ & - & - & 98.2 \\
$\times 30$ & 1 & 1.8 & 100.0 \\
\hline Total & 5.5 & 100.0 & \\
\hline
\end{tabular}

Alat ukur yang digunakan untuk mengumpulkan data terdiri atas 2 kuesioner dalam bentuk skala model Likert dengan kriteria jawaban yang berkisar antara sangat tidak setuju sampai sangat setuju (5 kategori). Kuesioner pertama mengukur kepuasan kerja dan kuesioner kedua mengukur motif berprestasi. Kuesioner tersebut dilengkapi dengan pertanyaan mengenai data demografik.

Validitas alat ukur dilakukan melalui $f a c e$ dan content validity by experts. Selanjutnya dilakukan juga item validity untuk memilih pernyataan yang sahth untuk diberikan kepada subyek penelitian. Setelah itu dilakukan uj reliabilitas dengan menggunakan perhitungan alpha Cronbachdan diperoleh nilai aipha untuk skala kepuasan kerja sebesar 0,8046 dan at phaurtuk skala molifberprestasi sebesar 0,8575.

Teknik Pengolahan data dilakukan dengan bantuan program SPSS versl 11,0 . Perhitungan statistik yang digunakan antara lain frekuensi, mean, standard deviation, uj korelasi molalui teknik Pearson product moment correlation dan uji $t$.

\section{Has I}

\section{Kopuasan kerja karyawan}

Bedasarkan pertitungan nilai minirnum dan maksimum dari variabel kepuasan kerja, dapat dilihat gambaran penyebaran nilai dari variabel tersebut pada seluruh subyek penelitian, seperti terlihat pada tabel of bawah ini.

Tabet 1.

Prosentase Kepuasan Kerja Karyawan

\begin{tabular}{cccc}
\hline $\begin{array}{c}\text { Rentang } \\
\text { Nilai }\end{array}$ & Frekuensi & Persentase & $\begin{array}{c}\text { Persentase } \\
\text { kumulatif }\end{array}$ \\
\hline $140-159$ & 1 & 1.8 & 1.8 \\
$160-179$ & 3 & 5.5 & 7.3 \\
$180-199$ & 20 & 36.4 & 43.6 \\
$200-219$ & 25 & 45.5 & 89.1 \\
$220-239$ & 5 & 9.1 & 98.2 \\
$240-259$ & 1 & 1.8 & 100.0 \\
\hline Tot: & 55 & 100.0 &
\end{tabular}

Dari tabel tersebut terlihat bahwa $45,5 \%$ karyawan memiliki nilai kepuasan kerja pada rentang nilai 200-219. Jika dibandingkan dengan nilai rerata seluruh subyek $(201,69)$ maka dapat dikatakan bahwa hampir separuh karyawan memiliki kepuasan kerja yang cukup bakk. Penyebaran nilai tersebut akan lebih jolas terlihat dalam gambar d bawah ini. 
Gambar 1.

Kepuasan kerja karyawan

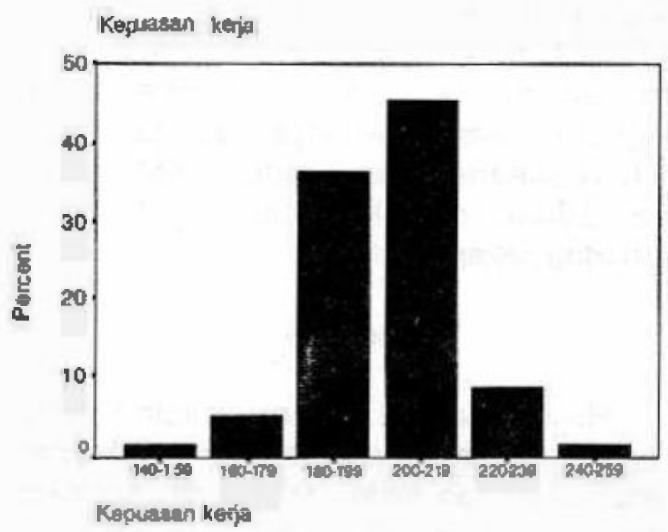

Hubungan antara kepuasan kerja dengan faktor demografi dan motif berprestasi

Ditinjau dari perhitungan korelasi antara motif berprestasi, usia, lama kerja dengan kepuasan kerja diperoleh gambaran seperti tertera pada tabel d bawah ini.

Tabel2.

Nilal Korelasi

\begin{tabular}{ccc}
\hline Variabed & Kepuasan Kerja & Slgnifikan \\
\hline Motif Berprestasi & $r=+0,3: 2$ & $P<0,05$ \\
Usia & $r=-0,325$ & $P<0,05$ \\
Lama Keria & $r=-0,459$ & $P<0,05$ \\
\hline
\end{tabular}

Berdasarkan tabel di atas dapat dikemukakan bahwa variabel motif berprestasi, usia dan lama kerja berkorelasi secara signifikan dengan kepuasan kerja. Tabel tersebut memperiihatkan bahwa motif berprestasi berkorelasi positif (agak rendah) dengan kepuasan kerja. Dengan demikian dapat dikemukakan bahwa semakin tinggi motif berprestasi subjek, kepuasan kerjanya juga cenderung semakin tinggi. Sementara usia dan lama kerja ternyata memperlihatkan korelasi yang negatif. Hal ini berarti semakin bertambah usia subjek, kepuasan kerjanya juga cen- derung semakin rendah. Begitu juga dengan lama kerja, semakin lama subjek bekerja di instansi tersebut, kepuasan kerjanya cenderung semakin rendah. Hubungan antara kedua faktor demografik dengan kepuasan kerja akan terthat lebih jelas pada gambar kurve dibawahini.

\section{Gambar 2.}

Hubungan antara usia dengan kepuasan kerja

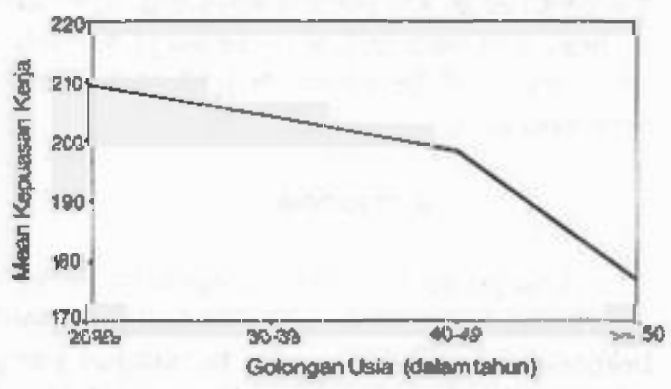

Dari gambar di atas terlihat bahwa semakin bertambah usia karyawan, semakin rendah nilai kepuasan kerjaanya. Kepuasan kerja terendah tampak pada karyawan dengan usia 50 tahun keatas. Begitu juga halnya dengan hubungan antara lama kerja dan kepuasan kerja, gambarannya akan lebih jelas terlihat meialui gambar berikut ini.

Gariber 3

Hubungan lama kerja dan kepuasan kerja

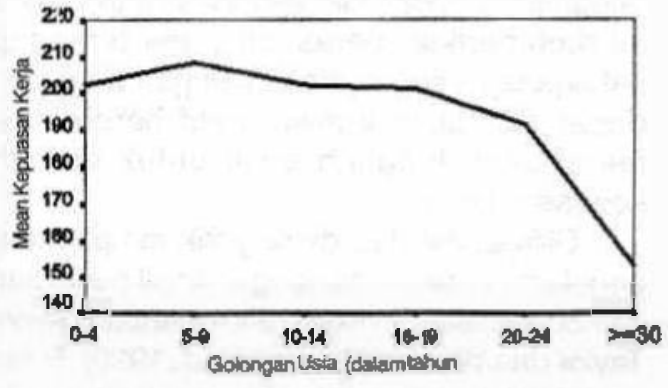

Dari gambar di atas tampak bahwa kepuasan kerja dirasakan tinggi pada karyawan dengan masa/lama kerja antara 5-9 tahun dan terihat menurun seiring bertambahnya masa kerja subyek Kepuasan kerja terendah terlihat 
pada karyawan dengan masa kerja 30 tahun keatas.

Selain hasil di atas, penelitian ini memperlihatkan bahwa tidak terdapat perbedaan yang signifikan dalam kepuasan kerja antara karyawan laki-laki dan karyawan perempuan (uji t-test dengan metode Lavene menunjukan nilai $F=0,096, p>0,05$ ). Begitu juga gambaran motif berprestasinya menunjukan tidak ada perbedaan yang signifikan antara motif berprestasi pada karyawan lakilaki dan motif berprestasi pada karyawan perempuan, $(f=1,107, p>0,05)$

\section{Pembahasan}

Hasil penelitian ini menunjukkan bahwa kepuasan kerja berhubungan dengan motif berprestasi. Ditilik dari nilai hubungan yang tidak begitu besar, dapat dikatakan bahwa motif berprestasi bukan faktor yang mempunyai peran besar dalam menciptakan kepuasan keria karena memang banyak faktor lain yang terkait dengan kepuasan kerja. Kendati demikian motif berprestasi menjadi variabel yang patut diperhitungkan dalam mengkaji kepuasan kerja. Jalinan hubungan antara kedua variabel tersebut diawali oleh adanya kebutuhan dan dorongan untuk bekerja sebaik mungkin. Hal ini membuahkan prestasi kerja dan prestasi kerja akan menghasilkan ganjaran baik berupa kenaikan gaji, kemajuan karir, penghargaan, dan lain-lain. Hasil dari semua ini memberikan perasaan puas terhadap pekerjaaan yang dijalani. Dengan demikian dapat dikatakan bahwa motif berprestasi merupakan langkah awal untuk meraih kepuasan kerja.

Ditinjau dari datademografik, tampakhasil penelitian ini berbeda dengan hasil penelitian dari Schultz dan Schultz (1990) maupun Glerm, TaylordanWeafer (dalamAsiad, 1990). Pada peneltilan mereka tingkat kepuasan kerja pria dan wanita berbeda, sedangkan hasi penellian ini menunjulkkan tidak ada perbedaan kepuasan kerja ditinjau dari aspek jenis kelamin. Begitu juga hubungan antara usia dan lama kerja dengan kepuasan kerja. Penelitian ini memperlihatkan adanya korelasi negatif antara kepuasan kerja dengan kedua variabel demografik tersebut. Pada peneitian ini tampak bahwa semakin lanjut usia sesorang dan semakin lama masa kerjanya, maka tingkat kepuasan kerjanya menurun. Bisa jadi kebosanan dan rutinitas pekerjaan menjadikan mereka tidak lagi tertarik terhadap pekerjaannya.

\section{Penutup}

Hasil penelitian ini menunjukan bahwa kepuasan kerja berkaitan dengan faktor motif berprestasi dan faktor demografi. Korelasi antara motif berprestasi dan kepuasan kerja tidak begitu tinggi, namun hal tersebut tetap mencerminkan bahwa kepuasan kerja ditentukan oleh seberapajauh seseorang terdorong untuk melakukan tugasnya sebaik mungkin. Berkaitan dengan faktor usia, hasil penelitian ini menunjukan bahwa karyawan dengan usia $20-29$ tahun memperlihatkan tingkat kepuasan kerja yang tinggi, sedangkan karyawan dengan usia lanjut (50 tahun keatas) memperlihatkan tingkat kepuasan kerja terendah. Ditinjau dari masa kerja, tampak bahwa kepuasan kerja tertinggi dirasakan oleh karyawan yang bekerja antara 5-9 tahın, sedangkan karyawan dengan masa kerja 30 tahun lebih merasakan kepuasan kerja yang rendah.

Adanya perbedaan hasil antara penelitian ini dengan penelitian lainnya seperti yang dilakukan oleh Schulz \& Schults ataupun peneliti lain diharapkan dapat memacu munculnya penelitian berikutnya yang mengkaji secara lebih mendalam peranan faktor demografi terhadap kepuasan kerja. Dalam hal ini kajian meta analisis diharapkan dapat memberikan jawaban yang lebih memuaskan.

Berdasarkan temuan hubungan yang signifikan antara motif berprestasi dan kepuasan kerja, instansi pendidikan seyogyanya dapat menyelenggarakan pelatihan untuk meningkatkan motivas| berprestasi agar karyawan dapat meraih kepuasan kerja yang tinggi. 


\section{Daftar Pus taka}

Anastasi, A. (1993). Bidang-bidang psikologi terapan (Penerj: Arjatmi). Jakarta: Rajawali Press.

As,ad, M. (1999). Seri ilmu sumber daya manusia: Psikologi industri ( edisi ke4). Yogyakarta: Liberty.

Drenth, Thierry, \& De Wolff, . (1998). Personnel psychology-handbook ofwork \& organizational psychology (Drenth, Thierry \& De Wolf, Ed). (edisi ke-2). London: Psychology Press Ltd.

Dubrin, A.J. (1997). Human relation: Ajob onented approach. Englewood Cliffs-New Jersey: Prentice Hall.

Greenberg, J. \& Baron, R.A. (1997). Behavior in organization: Understanding \& managing the human side of work (edisi ke6) Now Jersey: Prentice Hall.

Hall, C.S. \& Lindzey, G, (1993). Psikologi kepribadian: Teoniteori psikodinamik ( penerj: Yustinus ). Yogyakarta: Kanișius.
Hersey, P, Blanchard, K.h., Johnson, D.E. (1996). Management of organizational behavior-utilizing human resources. Upper Saddle River $\bar{n}$ New Jersey: Prentice Hall.

Kolb, D.A., Osland, J.S. \& Rubin, I.M., (1995). Organizational behavior-an experiment tal appraach (edisi ke-6). Englewood Ciffs-New Jersey: prentice Hall.

McCleland, D.C. (1987). Human motivation. New York Cambridge University Press

Munandar. A.S. (2001). Psikologi industri \& organisasi. Jakarta: UI Press

Robbins, S.P. (1996). Organizational behavior. New York: Prentice Hall.

Schultz, D.P., \& Schultz, S.E. (1990). PSy. chology and industry today: An intoduction to industrial and organizational psychology (edisi ke-5). New York: Mac. Millan.

Steers, R.M. Porter, L.W. \& Bigley, G.A. (1996). Motvationand leadershipat work (edisi ke-6). New York Mc Graw Hill. 